\title{
The Rowland Clark (41RR77) Site, Red River County, Texas : Editor's Introduction
}

Gegory Perino

Unknown

Leonard Blake

Carol J. Loveland

Follow this and additional works at: https://scholarworks.sfasu.edu/ita

Part of the American Material Culture Commons, Archaeological Anthropology Commons, Environmental Studies Commons, Other American Studies Commons, Other Arts and Humanities Commons, Other History of Art, Architecture, and Archaeology Commons, and the United States History Commons

Tell us how this article helped you.

This Article is brought to you for free and open access by the Center for Regional Heritage Research at SFA ScholarWorks. It has been accepted for inclusion in Index of Texas Archaeology: Open Access Gray Literature from the Lone Star State by an authorized editor of SFA ScholarWorks. For more information, please contact cdsscholarworks@sfasu.edu. 


\section{The Rowland Clark (41RR77) Site, Red River County, Texas : Editor's Introduction Creative Commons License (c) $($ ) $(9)$}

This work is licensed under a Creative Commons Attribution-NonCommercial 4.0 International License 


\title{
The Rowland Clark (41RR77) Site, Red River County, Texas
}

Gregory Perino

\author{
with contributions by Leonard Blake and Carol J. Loveland
}

\section{EDITOR'S INTRODUCTION}

The Rowland Clark (41RR77) and Dan Holdeman (41RR11) archaeological sites were excavated in the late 1970s and early 1980s by Gregory Perino of the Museum of Red River in Idabel, Oklahoma. Manuscripts on those investigations were prepared by Perino shortly after the conclusion of the work, but these were never published, remaining instead on file at the Museum of the Red River.

After discussions with Mary Herron of the Museum of the Red River, and Gregory Perino (now retired), the Friends of Northeast Texas Archaeology was granted permission to edit and publish the two manuscripts in two volumes of the Journal of Northeast Texas Archaeology. The Rowland Clark manuscript is being published in No. 4 of the journal, to be followed in 1995 with the Dan Holdeman report in No. 5.

There have been all too few recent archaeological investigations of Caddoan sites on the Red River in Northeast Texas (Kenmotsu and Perttula 1993; Bruseth 1994), with the notable exception of the Museum of the Red River's excavations at the Bob Williams (Perino 1983) site and the 1991-1992 Texas Archeological Society's field schools at the Roitsch, Fasken, Ray, and Saltwell Slough sites in Red River and Lamar counties (Bruseth et al. 1991, 1992). It is fair, but unfortunate, to state that this part of the Caddoan archaeological area remains poorly known (e.g., Perttula 1992a), while the looting and vandalism of important Caddoan sites along the Red River continues unabated (Perttula 1992b).

This makes the publication of Perino's work notable for two principal reasons. First, the Museum of the Red River excavations recovered significant archaeological data on the nature of Caddoan occupations from ca. A.D. 900 to 1600 in the Red River valley-including bioarchaeological and paleobotanical remains (see appendices by Blake and Loveland, this volume). And second, the publication of these reports will make this information available to Caddoan archaeologists and to all those interested in the prehistory and early history of the Caddoan peoples. 


\section{REFERENCES CITED}

Bruseth, James E.

1994 The Development of Caddoan Polities along the Middle Red River Valley of Eastern Texas and Oklahoma. In The Native History of the Caddo: Their Place in Southeastern Archaeology and Ethnohistory, edited by Timothy K. Perttula and James E. Bruseth. MS in submission.

Bruseth, James E., Nancy A. Kenmotsu, William A. Martin, Daniel J. Prikryl, Timothy K. Perttula, Jacque Jacquier, and Larry D. Banks

1991 Summary of the 1991 Field School in Red River County. Texas Archeology (Newsletter of the Texas Archeological Society) 35 (No. 3), pp. 1, 6-10.

Bruseth, James E., Larry D. Banks, William A. Martin, Daniel J. Prikryl, and Timothy K. Perttula

1992 The 1992 Field School: Soggy but Successful. Texas Archeology (Newsletter of the Texas Archeological Society) 36 (No. 3), pp. 1, 7-13.

Kenmotsu, Nancy A. and Timothy K. Perttula (editors)

1993 Archeology of the Eastern Planning Region of Texas: A Planning Document. Cultural Resource Management Report 3. Department of Antiquities Protection, Texas Historical Commission, Austin.

Perino, Gregory

1983 Archaeological Research at the Bob Williams Site, Red River County, Texas. Museum of the Red River, Idabel, Oklahoma.

Perttula, Timothy K.

1992a "The Caddo Nation": Archaeological and Ethnohistoric Perspectives. University of Texas Press, Austin.

1992b The Looting and Vandalism of Archaeological Sites in East Texas. ASCA Report, Volume 18, No. 2, pp. 3-13. American Society for Conservation Archaeology, Portales, New Mexico. 